\title{
塩基性条件下におけるニトリルオキシドからイソシアネートへ の異性化反応機構の理論的解明
}

\author{
石山 裕輝 ${ }^{\mathrm{a}}$, 林 慶浩 ${ }^{\mathrm{a}}$, 高田 十志和 ${ }^{\mathrm{a}}$, 川内 進 ${ }^{\mathrm{a}, \mathrm{b}^{*}}$ \\ a 東京工業大学物質理工学院，干 152-8552 東京都目黒区大岡山2-12-1-E4-6 \\ $\mathrm{b}$ 東京工業大学物質・情報卓越教育院(TAC-MI), 干 152-8552 東京都目黒区大岡山2-12-1 \\ *e-mail: kawauchi.s.aa@m.titech.ac.jp
}

(Received: December 13, 2019; Accepted for publication: December 23, 2019; Online publication: March 13, 2020)

Reaction mechanisms for the isomerization of nitrile $N$-oxide to isocyanate catalyzed by hydroxide ion were investigated by density functional theory calculations. In this mechanism, nitrile $N$-oxide first dimerizes to a sixmembered ring intermediate, and then undergoes two rearrangement reactions to isomerize into two isocyanate molecules. The process with the highest activation energy as an elementary reaction was the second rearrangement reaction, with an activation free energy of $31.1 \mathrm{kcal} / \mathrm{mol}$, which is reasonable for a reaction proceeding slowly at room temperature. This mechanism can also explain the experimental results that the oxygen atom exchanges between nitrile $N$-oxide molecules during the isomerization reaction.

キーワード: reaction mechanism, Nitrile $N$-oxide, Isomerization, DFT calculation

\section{1 研究背景と目的}

ニトリル $N$-オキシドはアルケン，アルキン，シアノ基 など様々な不飽和結合と，無触媒で 1-3 双極子付加環化 反応する [1]. この反応性のため, ニトリル $N$-オキシド は高分子の分子修飾や分子間の連結反応に応用可能な基 質として注目されている. しかしながら，ニトリル $-N-$ オキシドは通常不安定でScheme1に示すように, フロキ サンへの二量化反応 [2]や, イソシアネートへの異性化 反応 [3]により，容易に失活するという問題がある. 二 トリル $N$-オキシドの二量化反応を効果的に抑制する方 法は報告されている [4]一方, 異性化反応を効果的に抑 制する方法は報告されていない，さらに，異性化機構を 詳細に検討した例は少なく, 異性化機構は解明されてい ない. そこで本研究では, ニトリル $N$-オキシドの異性化 を抑制する手がかりを得るために, 異性化機構を量子化 学計算により検討した.

我々は過去の研究で, GRRM法 $[5,6]$ を用いてニトリ ル $N$-オキシドの単分子, 二分子の異性化経路の系統的探 索を行った [7]. その結果求まったエネルギー的に最も 有利な異性化経路は, Scheme 2 に示すようなジラジカル 中間体を経由する異性化経路であった。この経路では,

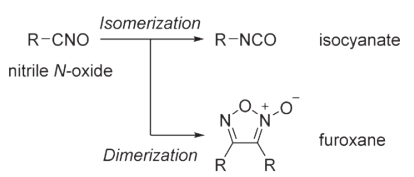

Scheme 1. Nitrile $N$-oxide isomerization to isocyanate and dimerization to furoxane.

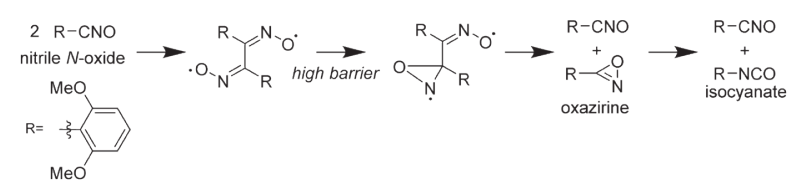

Scheme 2. Isomerization pathway of nitrile $N$-oxide to isocyanate via the diradical addition.

ニトリル $N$-オキシドが二量化しジラジカル中間体が生 じ，三員環中間体へ解離した後，イソシアネートへ異性 化する. この経路の中で, 素反応として最も活性化エネ ルギーが大きい過程はジラジカル中間体が 3 員環構造へ 閉環する過程で, $\Delta G^{\ddagger}=41.2 \mathrm{kcal} / \mathrm{mol}(1 \mathrm{kcal}=4.184 \mathrm{~kJ})$ と非常に大きな值であった.これは, ニトリル $N$-オキシ ドの異性化反応は単分子, 二分子のみでは熱的に進行し 


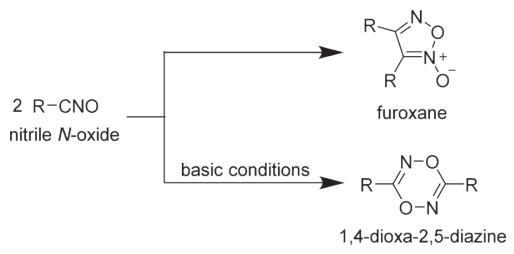

Scheme 3. Nitrile $N$-oxide dimerize to 1,4-dioxa-2,5-diazine under basic conditions.

難いことを意味する. したがって, 実際には異性化反応 は他の経路で進行すると考えられる.

中性条件下では，ニトリル $N$-オキシドの二量化反応に よりフロキサンが生成する. 一方で Scheme 3 に示すよう に，塩基性条件下ではニトリル $N$-オキシドの二量化反応 により，六員環構造を有する1,4-dioxa-2,5-diazineも生成 することが知られている [8]. 我々はこの事実に注目し, 水溶液中の水酸物イオン $\mathrm{OH}^{-}$が触媒として働き，二ト リル $N$-オキシド二分子から六員環の中間体を経て，イソ シアネートへ異性化する経路の検討を行った。

\section{2 計算方法}

全ての計算は Gaussian 16 プログラムで実行した，密 度汎関数には $\omega$ B97X-D を用い，基底系は 6-311+G (d,p) を用いた. 求められた各構造について振動計算を行い, 安定構造については虚数の振動数を持たないこと，遷移
状態については反応座標に対応するただ一つの虚数の振 動数を持つことを確認した.

\section{3 結果と考察}

今回我々は, ニトリル $N$-オキシドのモデル分子 $(\mathrm{R}=\mathrm{Me})$ を用いて検討した. Figure 1 には, 求まった経路 の反応のエネルギー戝が示されている。ニトリル $N$-オキ シドEQ1 とニトリル $N$-オキシドの $\mathrm{OH}^{-}$付加体 EQ1' は, head to tail型付加の遷移状態 TS1-2 $\left(\Delta G^{\ddagger}=26.2 \mathrm{kcal} / \mathrm{mol}\right)$ を経て EQ2 に至る. EQ2 は閉環の遷移状態 TS2-3 $(\Delta$ $\left.G^{\ddagger}=8.5 \mathrm{kcal} / \mathrm{mol}\right)$ を経て六員環中間体 EQ3 至る. 尚, EQ1 とEQ1' から一段階でEQ3 が生成するような，協奏 的な過程は見出されなかった。 EQ3 は二度の転位反応 の遷移状態TS3-4 $\left(\Delta G^{\ddagger}=24.0 \mathrm{kcal} / \mathrm{mol}\right)$ およびTS4-5 ( $\Delta$ $\left.G^{\ddagger}=31.2 \mathrm{kcal} / \mathrm{mol}\right)$ を経て, イソシアネート二分子 $(\mathbf{E Q 5}$, $\left.\mathrm{EQ5}^{\prime}\right)$ へ異性化する。一度目の転位反応では，Me基の転 移と同時に開環し，六員環構造が維持されないことがわ かった.

この経路の中で, 素反応として最も活性化エネル ギーが高いのは，二度目の転位反応(TS4-5)でその活性 化エネルギーは $\Delta G^{\ddagger}=31.1 \mathrm{kcal} / \mathrm{mol}$ であった。これは, 室温で緩やかに進行する反応として合理的な值である. さらに，この経路は同位体ラベル法を用いて得られた 「ニトリル $N$-オキシドがイソシアネートへ異性化する際 に，ニトリル $N$-オキシド分子間で $\mathrm{O}$ 原子を交換する」と いう実験結果 [9]を説明できる。

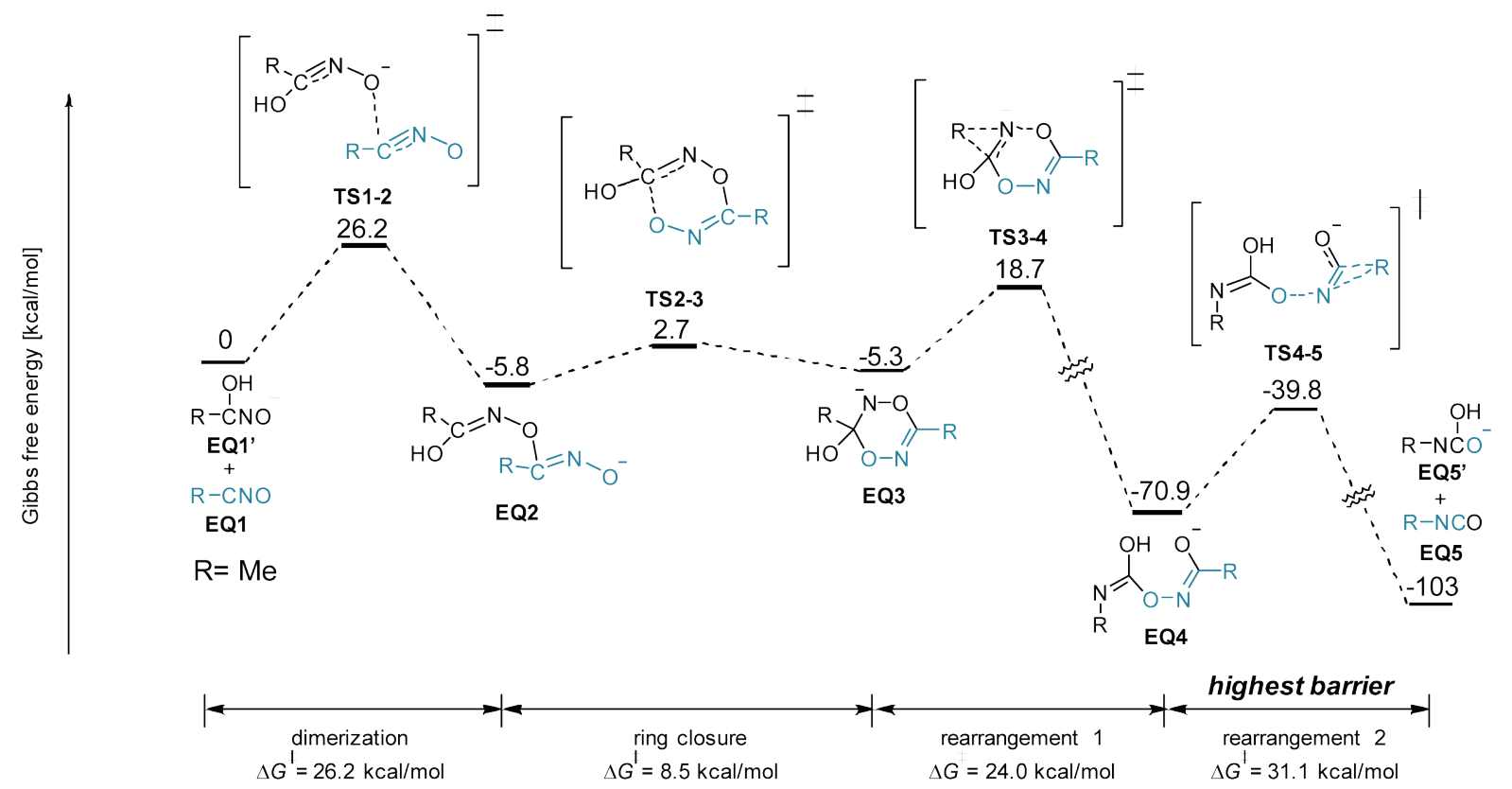

Figure 1. Isomerization pathway of nitrile $N$-oxide to isocyanate via six-membered ring intermediate catalyzed by hydroxide ion. 


\section{謝辞}

本論文の計算は東京工業大学のTSUBAME3.0 と自 然科学研究機構計算科学研究センターのスーパーコン ピュータを用いた。研究費を補助していただいたJST CREST (JPMJCR1522) とJSPS 科研費 (JP17K17720) に深 謝する。

\section{参考文献}

[1] H. Rolf, Angew. Chem. Int. Ed. Engl., 2, 565 (1963) DOI:10.1002/anie.196305651

[2] I. Crystal, M. Structure, Experientia, 26, 214 (1982).

[3] C. Grundmann, P. Kochs, Angew. Chem. Int. Ed. Engl.,
9, 635 (1970). DOI:10.1002/anie.197006351

[4] C. Grundmann, J. M. Dean, Angew. Chem. Int. Ed. Engl., 3, 585 (1964). DOI:10.1002/anie.196405852

[5] S. Maeda, K. Ohno, J. Phys. Chem. A, 109, 5742 (2005). DOI:10.1021/jp0513162, PMID:16833907

[6] S. Maeda, K. Morokuma, J. Chem. Theory Comput., 7, 2335 (2011). DOI:10.1021/ct200290m , PMID:26606607

[7] Y. Hayashi, Y. Ishiyama, T. Takata, S. Kawauchi, Eur. J. Org. Chem., 2019, 6646 (2019). DOI:10.1002/ ejoc.201901156

[8] F. D. Sarlo, A. Guarna, J. Chem. Soc., Perkin Trans. 1, 1825 (1976). DOI:10.1039/p19760001825

[9] G. A. Taylor, J. Chem. Soc., Perkin Trans. 1, 1181 (1985). DOI:10.1039/P19850001181 